\title{
A biostratigraphic revision of the Eocene and Oligocene foraminiferal type localities of Trinidad described by Cushman \& Stainforth (1945) and Cushman \& Renz (1948)
}

\author{
CAROLINE M MCCABE* \\ Research School of Geological \\ and Geophysical Sciences \\ Birkbeck College and \\ University College London, Gower Street, \\ London WC1E 6BT, U.K. \\ ${ }^{*}$ Current Affiliation: Geologische Institut, ETH- \\ Zentrum, CH-8092 Zürich, Switzerland.
}

\author{
MICHAEL A KAMINSKI \\ Research School of Geological \\ and Geophysical Sciences \\ Birkbeck College and \\ University College London, Gower Street, \\ London WC1E 6BT, U.K.
}

\author{
EDWARD FINCH \\ Research School of Geological \\ and Geophysical Sciences \\ Birkbeck College and \\ University College London, \\ Gower Street, \\ London WC1E 6BT, U.K.
}

\begin{abstract}
This study constitutes a revision and reappraisal of the samples used in the two classic studies of the calcareous benthic foraminifera of the Navet, San Fernando and Cipero Formations of Trinidad: Cushman \& Renz's 1948 study of the Eocene, and Cushman \& Stainforth's 1945 study of the Oligocene. Biostratigraphical calibration is achieved by reference to the lithological schemes of Bolli (1957) and other studies, and by directly assigning the samples to the standard planktonic foraminiferal and nannofossils zonal schemes. This direct calibration enables a more precise biostratigraphic framework for the type localities of 55 benthic foraminiferal taxa described by Cushman \& Renz and Cushman \& Stainforth. J. Micropalaeontol. 12 (2): 195200, December 1993.
\end{abstract}

\section{INTRODUCTION}

The island of Trinidad is of great importance to micropalaeontological research because the stratigraphic formations exposed on the island are extremely rich in microfauna. More importantly, Trinidad is the type locality for many of the Upper Cretaceous to Paleogene planktonic foraminiferal zones. The establishment of a detailed planktonic zonation scheme based on studies carried out in Trinidad (Bolli, 1966, reviewed in Bolli \& Saunders, 1985) facilitated the correlation of planktonic foraminiferal assemblages from other low-latitude localities. At the same time it made the construction of a cosmopolitan planktonic zonation scheme a viable possibility.

This project deals with the samples that comprise the type localities of foraminifera described from the Navet and San Fernando Formations (Cushman \& Renz, 1948) and the Cipero Formation (Cushman \& Stainforth, 1945) of Trinidad. Cushman, who based his age assignments on various criteria, dated these formations as ?Palaeocene to late Eocene and Oligocene respectively, but planktonic foraminiferal research since the 1940's (Bolli, 1957, Bolli 1959; Bolli \& Saunders 1985) has since provided much greater accuracy for determining the age of these sediments. Advances in both technology and biostratigraphy since Cushman's day makes re-examination of the faunas from these type localities worthwhile.

During a recent visit to the Smithsonian Institution, Washington D.C., one of us (MAK) traced the whereabouts of Cushman's original samples from the Eocene and Oligocene of Trinidad. In total, Cushman \& Renz and Cushman \& Stainforth described 55 new taxa of foraminifera from the Navet, San Fernando, and lower Cipero Formations, many of which to our knowledge have escaped the attention of subsequent workers (Appendix 1) The primary goal of this study is to revise the biostratigraphy of Cushman's type samples used in these classic studies with detailed observations, thereby providing more accurate age assignments for the type localities of foraminiferal taxa described by Cushman \& Renz and Cushman \& Stainforth. Because the lithostratigraphic units in Trinidad can be precisely dated by the use of nannofossils and planktonic foraminifera, this provides an excellent opportunity to calibrate bathyal benthic foraminifera to the standard low-latitude biostratigraphic framework. This study is part of a revision of the Paleogene benthic foraminifera described from Trinidad.

\section{PREVIOUS STUDIES}

The rich fossiliferous deposits of Trinidad have been studied since the middle of the nineteenth century. Knowledge of their micropalaeontology was already advanced by 1892, when Guppy published a general study of the "Microzoic Deposits of Trinidad" which spoke of a "series of grey marls" containing "Globigerina and other foraminifera". Detailed foraminiferal research of the Navet and Hospital Hill marls and the Cipero Formation was undertaken subsequently by Cushman \& Renz (1948) and Cushman \& Stainforth (1945).

\section{Navet Formation}

In 1948, Cushman \& Renz described the extremely rich foraminiferal fauna that had been deposited in "typical marine, open sea and warm water" environmental conditions similar to those of the underlying Lizard Springs Formation (Cushman \& Renz, 1946) and the overlying 
Cipero Formation. The Navet formation was characterised by "light gray and greenish-gray, khaki-weathering marls and marly clays". It displayed no "continuous or undisturbed outcrop sections" but in southern Trinidad was seen to grade conformably down into the Lizard Springs Formation and up into the overlying Hospital Hill marl. A stratigraphic sequence based upon faunal evidence was identified from top to bottom (see Cushman and Renz, 1948 for exact localities):

\section{Penitence Hill marl}

Fitt Trace - Navet River - Nariva River marl Friendship Quarry - Dunmore Hill marl Ramdat marl

Cushman \& Renz dated the Navet Formation as occurring between the "Upper Cretaceous" Lizard Springs Formation and below the upper Eocene Hospital Hill marl. They believed it thus to be "?Palaeocene to lower-middle Eocene". The age was based upon the occurrence of the genus Hantkenina, present throughout the Navet Formation, excluding the Ramdat marl. This indicated that the Ramdat marl at the base of the Formation had an age of "older than early Eocene" (Cushman \& Renz, 1948). The Paleogene Formations of Trinidad are described below.

\section{San Fernando Formation.}

The San Fernando Formation contained a rich foraminiferal fauna between the Navet and Cipero Formations but there were a number of species restricted to it. These were typified by Hantkenina alabamensis Cushman var. primitiva Cushman \& Jarvis and, more rarely, Bulimina jacksonensis Cushman, which led Cushman \& Renz to regard this fauna as "typically upper Eocene" in age. Bolli (1957b) believed Cushman \& Renz's stratigraphic sequence to be "tentative", as it was based on "isolated, small outcrops and subsurface occurrences". In attempting to provide a planktonic zonation scheme, he strove to counterbalance these unfavourable conditions by studying a large number of samples. Age assignments for the Navet and San Fernando Formations can be compiled by reference to Bolli (1957b) who calibrated his samples by means of planktonic foraminifera (Figure 1).

\begin{tabular}{|l|l|}
\hline Planktonic Foraminiferal Zone & Type Locality \\
\hline $\begin{array}{l}\text { Globigerapsis semiinvoluta Zone } \\
\text { Truncorotaloides rohn Zone }\end{array}$ & Hospital Hill formation \\
\hline $\begin{array}{l}\text { Porticulasphaera mexicana Zone } \\
\text { Globorotalia lehneri Zone }\end{array}$ & $\begin{array}{l}\text { Penitence Hill marl } \\
\text { Globigerapsis kugleri Zone } \\
\text { Hantkenina aragonensis Zone } \\
\text { Globorotalia palmerae Zone }\end{array}$ \\
\hline
\end{tabular}

Fig 1. Planktonic foraminiferal zones in the Eocene of Trinidad, from Bolli (1957).

In 1959, Bolli revised his planktonic zonation scheme of S.E. Trinidad. He reassessed the chronostratigraphy of the
Navet and San Fernando Formations and regarded them as upper lower Eocene to lower upper Eocene, and uppermost Eocene respectively. Bolli's chronostratigraphy can be updated by comparing his original scheme to the tabulated planktonic foraminiferal zonal schemes of Toumarkine \& Luterbacher and Bolli \& Saunders in Plankton Stratigraphy (1985), and also to the revised P-zones of Berggren \& Miller (1988).

Revision of the chronostratigraphy by these authoritative studies reveals that the samples can be dated accordingly: the Navet Formation samples extend from Zone P10 (Friendship Quarry marl) through P11 (Dunmore Hill marl), Zone P12 (including both the Navet River and Near Fitt Trace marls) and Zone P13 (Penitence Hill marl). The age of the Hospital Hill marl proved more difficult to establish - Bolli (1957) tentatively assigned it to the T. rohri and G. semiinvoluta Zones, which correlate to Zones P14 and P15.

\section{Cipero Formation.}

Research on the Cipero Formation suggested a variety of ages. Cushman \& Stainforth (1945) stated that Nuttall's (1928) dating of this formation as Oligocene to Miocene had been revised by Cushman, with other collaborators, as Eocene. Cushman \& Stainforth again revised the age correlating the Cipero Formation with the Oligocene. These authors subdivided the Cipero Formation into three zones:

Zone I (the lower Globigerina concinna Zone) rests conformably on top of the Hospital Hill marl but does not contain its characteristic fauna of Bulimina jacksonensis and Hantkenina alabamensis. This zone was dated as lower Oligocene to "middle" Oligocene.

The "Bamboo Clay" unit divides Zone I from Zone II yielding an age of "middle" Oligocene by the occurrence of larger foraminifera of the genus Lepidocyclina (Vaughan \& Cole, 1941).

Zones II and III [middle (Globigerinatella insueta) and upper (Globorotalia fohsi) Zones] are positioned above the "Bamboo Clay" and were regarded as " not older than middle Oligocene."

In 1957, Bolli added another zone to that of Cushman \& Stainforth's scheme, and in his 1959 study of planktonic foraminifera from the Cipero Formation, Bolli regarded it as lower Oligocene to lower Miocene. The Cipero Formation is now regarded as extending from the lower Oligocene to the lower middle Miocene (Bolli \& Saunders 1985) (figure 2).

\section{MATERIAL AND METHODS}

\section{Material}

This study is based upon samples taken both from the original studies of Cushman \& Renz/Cushman \& Stainforth preserved at the Smithsonian Institution (USNM), and from the micropalaeontology collections of University College London. A full list of the samples is given in Table 1. Six samples were used from among those collected by Cushman \& Renz for their 1948 study of the Navet and Hospital Hill localities. The ages of these samples are reassessed based on their planktonic foraminifera and 


\begin{tabular}{|c|c|c|c|}
\hline \multirow[b]{2}{*}{ Formation } & \multirow[b]{2}{*}{$\begin{array}{l}\text { Lithostratigraphic } \\
\text { Unit (Informal) }\end{array}$} & \multicolumn{2}{|c|}{ Chronostratigraphy } \\
\hline & & $\begin{array}{l}\text { Cushman \& Statnforth } 1945 \\
\text { Cushman \& Renz } 1948\end{array}$ & $\begin{array}{c}\text { Bolll 1957; Bolll \& } \\
\text { Saunders } 1985\end{array}$ \\
\hline Lengua & & Early Miocene & \multirow{3}{*}{ Miocene } \\
\hline \multirow{3}{*}{ Cipero } & \multirow{3}{*}{$\begin{array}{l}\text { Zone III } \\
\text { Zone II } \\
\text { "Bamboo Clay" } \\
\text { Zone. } 1\end{array}$} & \multirow[b]{3}{*}{ Oligocene } & \\
\hline & & & \\
\hline & & & Oligocene \\
\hline San Fernando & Hospital Hill mart & Late Eocene & \multirow{2}{*}{ Late Eocene } \\
\hline \multirow[b]{2}{*}{ Navet } & \multirow[b]{2}{*}{$\begin{array}{l}\text { Penitence Hill mart } \\
\text { Fitt Trace marl } \\
\text { Navet River mart } \\
\text { Dunmore Hill marl } \\
\text { Friendship Quarry }\end{array}$} & \multirow[b]{2}{*}{$\begin{array}{l}\text { Early-Middle } \\
\text { Eocene }\end{array}$} & \\
\hline & & & Middle Eocene \\
\hline \multirow{2}{*}{ Lizard Springs } & & & Early Eocene \\
\hline & & & Palaeocene \\
\hline
\end{tabular}

Fig 2. Lithostratigraphy and chronostratigraphy of the studied formations, based on published sources.

nannofossil content. An additional sample was examined from Cushman \& Stainforth's 1945 study of the Cipero Formation. This sample was labelled "lower Globigerina concinna Zone". A second original sample (labelled "Globigerinatella insueta Zone") and a third ("Globorotalia fohsi Zone") have been dated as Miocene and so were beyond the scope of this study. For the purposes of comparison, four samples were also studied from the U.C.L. Collection of type localities from the San Fernando and Cipero Formations. One of these samples coincided with the Cushman \& Renz samples, in that it was collected from the Hospital Hill type locality. The remaining three samples were relevant to the Cushman \& Stainforth study. The first of these was a sample from the type locality of the Globigerina ciperoensis ciperoensis Zone. The remaining two samples were from the Globorotalia opima opima and Globorotalia kugleri Zone type localities.

\section{Methods}

All the samples used in this study had previously been washed, and no further preparation was needed. The samples were picked, divided into benthic and planktonic foraminifera and mounted onto faunal reference slides. Preservation of the specimens was good, except in the Friendship Quarry and Dunmore Hill marl samples in which the planktonic foraminifera displayed calcitic overgrowths.

Planktonic foraminifera were collected in order to facilitate a direct calibration to the standard planktonic foraminiferal zonations. For the Eocene Navet and San Fernando Formations, the zonation scheme of Berggren \& Miller (1988) was used throughout this study. The same procedure was adopted for updating the biostratigraphy of the Cipero Formation samples; using zonal schemes of Bolli (1957), Bolli \& Premoli Silva (1973), Bolli \& Saunders (1985), against which the P-zones of Berggren \& Miller (1988) were compared.

Nannofossil slides were made from each sample either by picking small fragments of loose matrix or by selecting several planktonic foraminifera and crushing them to free the matrix enclosed within. The smear preparation technique was used whereby a drop of distilled water was added to the crushed sediment on the slide, smeared and then dried on a hot plate. Ultraviolet light curing mounting medium was used to fix the coverslip. All slides are housed in the Micropalaeontological Collections of University College London. The recorded nannofossil assemblages have been interpreted in terms of Martini's (1971) worldwide zonal scheme. In some instances the nominate taxa for the Martini zones have not been recognised during this study. However, the assemblages are diverse and contain many of the species that are characteristic of the particular Martini zone cited in this text. The stratigraphic range of some taxa have been derived from Perch-Nielsen (1985).

\section{RESULTS}

\section{Biostratigraphical Calibration}

Calibrating the biostratigraphical ranges of the benthic foraminifera to the standard planktonic framework necessitated examining characteristic planktonic foraminiferal species in each sample and comparing the zonal assignments yielded by the planktonic specimens with the benthic foraminiferal data. Using the zonal scheme of Berggren \& Miller (1988), planktonic zonal markers were identified in all of the samples and the results are listed in Table 1.

\section{Friendship Quarry marl}

This sample correlates with the upper part of Zone P10, based upon the occurrence of Hantkenina nuttalli and $H$. dumblei. The sample also contained Acarinina, Truncorotaloides, and Hantkenina mexicana but did not contain Morozovella aragonensis, Globigerinatheka mexicana, kugleri or Hantkenina alabamensis, which would indicate a younger age. The nannofossil assemblage in this sample is poor. Specimens are poorly preserved and display much syntaxial overgrowth. Taxa recorded include Discoaster deflandrei, D. binodosus, D. nodifer, D. septemradiatus, Sphenolithus furcatolithoides, S. radians, Chiasmolithus grandis, and Reticulofenestra dictyoda. This assemblage indicates Zone NP15, corresponding to Zones P10-P11. 


\begin{tabular}{|c|c|c|c|c|}
\hline \multirow{2}{*}{$\begin{array}{l}\text { Sample Designation } \\
\text { AMNH 386. Friendship Quary. Near } 5 \text { mile post } \\
\text { of San Fernando - Princess Town Road. }\end{array}$} & \multirow{2}{*}{$\begin{array}{c}\text { Formation } \\
\text { Navet }\end{array}$} & \multicolumn{2}{|c|}{$\begin{array}{c}\text { Age } \\
\text { Foram/Nanno }\end{array}$} & \multirow{2}{*}{\begin{tabular}{|c} 
Repository \\
USNM
\end{tabular}} \\
\hline & & P10 & NP16 & \\
\hline $\begin{array}{l}\text { AMNH } 387 \text { Dunmore Hill mart. } \\
\text { Hinduston-Monkey Town Road Junction, } \\
\text { Dunmore Hill Area }\end{array}$ & Navet & P12 & NP15 & USNM \\
\hline $\begin{array}{l}\text { AMNH } 388 \text { Navet River mant. East Central } \\
\text { Range }\end{array}$ & Navet & P11 & indet. & USNM \\
\hline $\begin{array}{l}\text { AMNH } 389 \text { Near Fitt Trace. Conapo Southem } \\
\text { Road, } 17.25 \text { mile post }\end{array}$ & Navet & P12 & indet & USNM \\
\hline AMNH 390 Penitence Hil mart. Penitence Hill & Navet & P13 & indel & USNM \\
\hline $\begin{array}{l}\text { AMNH } 391 \text { Hospital Hill marl. San Fernando, } \\
\text { West slope of Hospital Hill }\end{array}$ & $\begin{array}{l}\text { San } \\
\text { Fernando }\end{array}$ & P15 & NP18 & USNM \\
\hline $\begin{array}{l}\text { Slop } 9 \text { Hospital Hill marl. Pointe-a-Pierre. Type } \\
\text { locality of the Globigerapsis seniinvoluta Zone }\end{array}$ & $\begin{array}{l}\text { San } \\
\text { Femando }\end{array}$ & P15 & NP18 & UCL. \\
\hline $\begin{array}{l}\text { Stop } 15 \text { Type locality of the Globorotalia } \\
\text { opima opima Zone }\end{array}$ & Cipero & $\begin{array}{l}\text { P20. } \\
\text { P21 }\end{array}$ & NP24 & UCL \\
\hline $\begin{array}{l}\text { Stop } 16 \text { Type Locality of the Globigerina } \\
\text { ciperoensis ciperoensis Zone }\end{array}$ & Cipero & P22 & indet. & UCL \\
\hline $\begin{array}{l}\text { AMNH } 380 \text { "bwer Globigerina concinna Zone, } \\
\text { South of San Fernando" [= Sample Rz.90] }\end{array}$ & Cipero & $\begin{array}{l}\text { P20- } \\
\text { P21 }\end{array}$ & NP24 & USNM \\
\hline $\begin{array}{l}\text { Stop } 8 \text { Mosquito Creek, Co-Type Locality of the } \\
\text { Globorotalia kugleri Zone }\end{array}$ & Cipero & P22-N4 & $\begin{array}{l}\text { NP25 } \\
-N N 1\end{array}$ & UCL \\
\hline
\end{tabular}

Table 1. Samples examined; see text.

\section{Navet River marl}

This sample was originally thought to be from Zone P12 (Morozovella lehneri), but is here reassigned to the uppermost part of Zone P11 based upon the occurrence of Morozovella aragonensis, Hantkenina dumblei and Globigerinatheka mexicana barri. Specimens of Globigerinatheka mexicana mexicana, Morozovella lehneri, Subbotina frontosa and a transitional form between Turborotalia cerroazulensis pomeroli and $T$. cerroazulensis posagnoensis were also present. This sample did not yield nannofossils.

\section{Near Fitt Trace marl}

This sample correlates with the middle part of Zone P12. Globigerinatheka subconglobata curryi was present, as well as two specimens that are transitional to Globigerinatheka subconglobata euganea. Turborotalia cerroazulensis pomeroli, Morozovella lehneri and Hantkenina dumblei were also present. However Morozovella aragonensis and Orbulinoides beckmanni were not found. The nannofossils in this sample were indeterminate because of their low abundance and poor preservation.

\section{Dunmore Hill marl}

Bolli (1957b) described his sample as occurring in the Globigerapsis kugleri Zone (= Zone P11 of Berggren \& Miller 1988). Cushman \& Renz's sample from the Dunmore Hill marl correlates with the upper part of Zone P12 based on the presence of Hantkenina alabamensis and Globigerinatheka subconglobata euganea. Orbulinoides beckmanni was not found in this sample. A diverse, but only moderately abundant assemblage of nannofossils was recorded from this sample. Principal taxa are Sphenolithus furcatolithoides, S. predistentus, Chiasmolithus grandis, Reticulofenestra umbilica, Discoaster barbadiensis, and $D$. saipanensis. This assemblage is characteristic of Zone NP16, which corresponds to Zones P12-P13. The presence of a few specimens of $D$. saipanensis indicates this sample is from the upper part of Zone NP16.

\section{Penitence Hill marl}

The presence of Orbulinoides beckmanni indicates that this sample is from Zone P13. Truncorotaloides rohri, Hantkenina alabamensis, Clavigerinella eocanica eocanica and Morozovella spinulosa were also present. The nannofossils in this sample were indeterminate because of their low abundance and poor preservation.

\section{1 \& Stop 9: Hospital Hill marl}

Previous studies were unable to establish a precise age for this sample. However we determined that Sample 391 correlates with the lower part of Zone P15. This age is based upon the presence of Globigerinatheka semiinvoluta, and the co-occurrence of Clavigerinella eocaenica eocaenica and C. eocaenica jarvisi, which become extinct in the middle of Zone P15. Because muricate forms should have been extinct by the late Eocene, the discovery of a couple of specimens of Acarinina leads us to believe that this sample experienced slight reworking or contamination. However, the sample contains high relative abundances of Turborotalia cerroazulensis, $T$. cocoaensis, and Catapsydrax dissimilis, which are typical for the late Eocene in the Atlantic. This sample contains a poorly-preserved, lowabundance nannofossil assemblage consisting of late Eocene and reworked early to middle Eocene taxa. The in-situ late Eocene taxa include Cyclicargolithus floridanus, Ericsonia formosa, Discoaster barbadiensis, D. saipanensis, Reticulofenestra umbilicus, Sphenolithus predistentus, S. radians, and Helicosphaera euphratis. This total assemblage is characteristic of Zone NP18. Early to middle Eocene taxa present in the assemblage include Discoaster lodoensis (common) and D. keupperi.

The "Stop 9 "sample was dated as Zone P15 because it also contains Globigerinatheka semiinvoluta in addition to the above species, but without Clavigerinella and the muricate forms. However, this sample yielded a mixed assemblage of early late Eocene and early to middle Eocene nannofossils. The in-situ late Eocene taxa include Discoaster saipanensis, D. barbadiensis, Dictyococcites bisecta, Sphenolithus predistentus, Cribrocentrum reticulatum, Reticulofenestra 
umbilica, Ericsonia formosa, and Helicosphaera euphratis. This assemblage is considered to be typical of Zone NP18, which corresponds to Zone P15. Early to middle Eocene taxa also present in this assemblage include Discoaster lodoensis, $D$. keupperi, and Sphenolithus spiniger.

\section{Globigerina concinna and Stop 15: Globorotalia opima} opima Zone

Sample 380 is known also as sample "Rz. 90", and in 1957 Bolli designated it as the type sample of the Globorotalia opima opima Zone (P20/P21 late Oligocene). The presence of Globorotalia opima opima in both of these samples confirms this assignment. Sample 380 contains a reasonably diverse but sparse nannofossil assemblage with Sphenolithus distentus, Helicosphaera recta, Dictyococcites bisecta, Cyclicargolithus floridanus, H. euphratis, and S. moriformis. Although this is a poor assemblage in terms of numbers of individuals, the co-occurrence of $S$. distentus and $H$. recta is typical of Zone NP24, corresponding to foraminiferal Zone P21.

\section{Stop 16: Globigerina ciperoensis ciperoensis Zone}

Globigerina ciperoensis ciperoensis is observed in this sample, indicating Zone P22. It had not been found in the sample from the Globorotalia opima opima Zone. The sample yielded an assemblage of long-ranging nannofossil taxa, including Coccolithus pelagicus, Helicosphera euphratis, Cyclicargolithus floridanus, and Discoaster deflandrei.

\section{Stop 8: Globorotalia kugleri Zone}

This sample was characterised by the presence of Globorotalia kugleri, thus giving it an age of latest Oligocene. However, the nannofossil assemblage from this sample was poor and lacked age-diagnostic taxa. The assemblage included Triquetrorhabdulus carinatus, Cyclicargolithus floridanus, C. abisectus, Discoaster(?) druggii, D. deflandrei, and Helicosphaera euphratis. This poor assemblage is probably indicative of the early Miocene Zone NN1 based upon the presence of a poorly preserved single specimen of $D$. druggii; otherwise the assemblage ranges from late Oligocene to early Miocene (NP25 to NN1).

\section{CONCLUSIONS}

The results of our planktonic foraminiferal and nannofossil analyses provide a chronostratigraphic framework for revising the classic taxonomic studies of Cushman and Renz (1948) and Cushman and Stainforth (1945). Our age calibrations of Cushman's samples and those of previous studies although substantially similar, show clear points of differentiation. Sample 388 (Navet River marl), thought previously be Zone P12 in age, is now reassigned to the upper part of Zone P11. A distinct change in the stratigraphic sequence can be seen in Sample 387 (Dunmore Hill marl). The Dunmore Hill marl was previously thought to be in Zone P11, but Cushman's sample is here reassigned to the upper part of Zone P12. It is possible that this sample was not taken exactly from the type locality of the Dunmore Hill marl, or that more than one "P zone" was exposed at the Dunmore Hill locality. This is possible, because the Navet Formation's stratigraphic sequence is tentative, with samples taken from "isolated, small outcrops" (Bolli 1957). Finally, the Hospital Hill Marl locality of the San Fernando Formation was determined to be strongly affected by reworking from lower/middle Eocene strata.

\section{ACKNOWLEDGEMENTS}

The authors express their gratitude to Brian Huber and the Department of Paleobiology, National Museum of Natural History, Smithsonian Institution, for the loan of Cushman's samples, and to Jeremy Young and John Whittaker (British Museum (Natural History)) for reviewing the manuscript. CMM was supported by a NERC Advanced Lower Studentship at University College London. Travel support for MAK was provided by a Short-Term Visiting Fellowship from the Smithsonian Institution.

\section{Manuscript received September 1992 \\ Manuscript accepted June 1993}

\section{Appendix 1}

CMM and MAK are currently revising the new species described by Cushman \& Renz (1948) and Cushman \& Stainforth (1945). Below is a list of these taxa with their revised type levels.

\begin{tabular}{|c|c|c|c|}
\hline New Species & olotype No. & Sample No & Age \\
\hline ishman \& Renz & & & \\
\hline Pelosina dubia & 57504 & AMNH390 & P13 \\
\hline Lituotuba eocenica & 57197 & AMNH388 & P11 \\
\hline Spirosplectammina trinitatensis & 57395 & AMNH391 & P15 \\
\hline Pseudoclavulina trinitatensis & 57064 & AMNH387 & P12 \\
\hline Plectina trinitatensis & 57217 & AMNH388 & P11 \\
\hline Rectogümbelina trinitatensis & 57244 & AMNH388 & P11 \\
\hline $\begin{array}{l}\text { Ellipsoglandulina glabra } \\
\text { ushman \& Stainforth (1945) }\end{array}$ & 57020 & AMNH386 & P10 \\
\hline Ammovertella retrorsa & 43317 & AMNH380 & $\mathrm{P} 20 / \mathrm{P} 21$ \\
\hline Valmulina guppyi & 43327 & Zone II & \\
\hline Gaudryina pseudocollinsi & 43331 & AMNH380 & $\mathrm{P} 20 / \mathrm{P} 21$ \\
\hline Dorothia brevis & 43338 & AMNH380 & $\mathrm{P} 20 / \mathrm{P} 21$ \\
\hline Karrieiella alticamera & 43359 & Zone III & \\
\hline Schenkiella suteri & 43365 & Zone II & \\
\hline Chrysalogonitum ciperense & 43474 & AMNH380 & P20/P21 \\
\hline Chrysalogonitum aspertum & 44033 & Zone II & \\
\hline Lagena ciperensis & 43530 & AMNH380 & $P 20 / P 21$ \\
\hline Lagena waringi & 43532 & Zone III & \\
\hline Lagena rutschi & 43536 & AMNH380 & $P 20 / P 21$ \\
\hline Rectogümbelina inopinata & 43587 & AMNH380 & $\mathrm{P} 20 / \mathrm{P} 21$ \\
\hline Plectofrondicularia ruthvenmurrayi & 43598 & Zone III & \\
\hline Plectofrondicularia muttalli & 43612 & Zone II & \\
\hline Nodogeneria rohri & 43618 & Zone III & \\
\hline Bulimina (Desinobulimina) illingi & 43638 & Zone III & \\
\hline Entosolenia spinolaminata & 43668 & Zone III & \\
\hline Entosolenia pannosa & 43663 & Zone III & \\
\hline Entosolenia kugleri & 43691 & Zone III & \\
\hline Virgulina ciperana & 43700 & Zone II & \\
\hline Unigerina ciperana. & 43722 & AMNH380 & $\mathrm{P} 20 / \mathrm{P} 21$ \\
\hline Pleurostomella praegerontica & 43767 & Zone II & \\
\hline Nodosarella reflecta" & 43791 & AMNH380 & $\mathrm{P} 20 / \mathrm{P} 21$ \\
\hline Ellipsoglandulina robustior & 43847 & Zone III & \\
\hline Ellipsolagena barri & 43858 & Zone II & \\
\hline Annulopatellina advena & 43863 & Zone III & \\
\hline
\end{tabular}


Discorbis ciperensis Gyroidina altispira

Gyroidina jarvisi

Pullenia trinitatensis

Planulina renzi
Gyroidina complanata

\section{New Varieties}

\begin{tabular}{|c|c|c|c|}
\hline \multicolumn{4}{|c|}{ Gaudryina pseudocollonsi Cushman \& Stainforth } \\
\hline var primitioa Cushman \& $\operatorname{Ren} z$ & 57405 & AMNH391 & P15 \\
\hline \multicolumn{4}{|c|}{ Ellipsonodosaria muttalli Cushman \& Jarvis } \\
\hline var aculeata Cushman \& Renz & 57461 & AMNH391 & P15 \\
\hline \multicolumn{4}{|l|}{ Pulvinulinella atlantisae Cushman } \\
\hline var dissonata Cushman \& Renz & 57353 & Nariva River marl & \\
\hline \multicolumn{4}{|c|}{ Marginulina sublituus (Nuttall) } \\
\hline var multicanterata Cushman and Stai & inforth & 43409 & Zone III \\
\hline \multicolumn{4}{|l|}{ Lagena pulcherrima Cushman \& Jarvis } \\
\hline var enitens Cushman \& Stainforth & 43512 & AMNH380 & $\mathrm{P} 20 / \mathrm{P} 21$ \\
\hline \multicolumn{4}{|l|}{ Lagena striata (d'Orbigny) } \\
\hline var basisenta Cushman \& Stainforth & 43517 & Zone III & \\
\hline \multicolumn{4}{|c|}{ Lagena crenata Parker \& Jones } \\
\hline var capistrata Cushman \& Stainforth & 43522 & Zone III & \\
\hline \multicolumn{4}{|c|}{ Pyrulina cylinoides (Roemer) } \\
\hline var curtatura Cushman \& Stainforth & 43567 & AMNH380 & $\mathrm{P} 20 / \mathrm{P} 21$ \\
\hline \multicolumn{4}{|l|}{ Plectofrondicularia morreyae Cushman } \\
\hline var exigua Cushman \& Stainforth & 43605 & Zone III & \\
\hline \multicolumn{4}{|c|}{ Plectofrondicularia nuttalii Cushman \& Stainforth } \\
\hline var acuta Cushman \& Stainforth & 43614 & Zone III & \\
\hline \multicolumn{4}{|c|}{ Entosoleria flinitiana (Cushman) } \\
\hline var plicatura Cushman \& Stainforth & 43657 & AMNH380 & P20/P21 \\
\hline \multicolumn{4}{|c|}{ Entosolenia flinitiana (Cushman) } \\
\hline var indomita Cushman \& Stainforth & 43662 & Zone III & \\
\hline \multicolumn{4}{|c|}{ Entosolenia crenulata (Coryell \& Rivero) } \\
\hline var multispinata Cushman \& Stainfo & rth 43694 & Zone III & \\
\hline \multicolumn{4}{|c|}{ Pleturostomella bierigi Palmer \& Bermudez } \\
\hline var hebata Cushman \& Stainforth & 43752 & Zone II & \\
\hline \multicolumn{4}{|c|}{ Gyroidina girardana (Reuss) } \\
\hline var perampla Cushman \& Stainforth & 43873 & Zone II & \\
\hline
\end{tabular}

\section{Manuscript received September 1992} Manuscript accepted June 1993
AMNH380 P20/P21

Zone III

Zone III

Zone III

AMNH380 P20/P21

Zone III

\section{Bolli}

\section{REFERENCES}

Berggren, W.A. \& Miller, K.G. 1988. Paleogene tropical planktonic foraminiferal biostratigraphy and magnetobiochronology. Micropalaeontology, 34, 362-380.

Bolli, H.M. 1957. Planktonic Foraminifera from the Eocene Navet and San Fernando Formations of Trinidad, B.W.I Bulletin U.S. National Museum 215, 155-172.

Bolli, H.M. 1959. Planktonic Foraminifera as index fossils in Trinidad, West Indies and their value for worldwide Stratigraphic Correlation. Ecologicae Geologicae Helvetiae, 52, 627-637.

Bolli, H.M., \& Saunders J.B. 1985. Oligocene to Holocene low latitude planktic foraminifera. In Bolli H.M., Saunders J.B. \& Perch Nielsen K., (Eds.) Plankton Stratigraphy. Cambridge University Press.

Bolli, H.M. 1966. Zonation of Cretaceous to Pliocene marine sediments based on Planktonic foraminifera. Bolentino Informativo Asociacion Venezolana de Geologia, Mineria y Petroleo, 9, 3-32.

Cushman, J.A. \& Renz, H.H. 1946. The Foraminifera of the Lizard Springs Formation of Trinidad, B.W.I.. Cushman Laboratory for Foraminiferal Research, Special Publication 18, 148.

Cushman, J.A. \& Renz, H.H. 1948. Eocene Foraminifera of the Navet and Hospital Hill Formations of Trinidad, B.W.I. Cushman Laboratory for Foraminiferal Research, Special Publication 24, 1-42.

Cushman, J.A. \& Stainforth, R.M. 1945. The Foraminifera of the Cipero Marl Formation of Trinidad, B.W.I. Cushman Laboratory for Foraminiferal Research, Special Publication 14, 175.

Guppy, L. 1892. The Tertiary Microzoic Formation of Trinidad, West Indies. Quarterly Journal of the Geological Society, 48, 519541

Martini, E. 1971. Standard Tertiary and Quaternary calcareous nannoplankton zonation. In: Proceedings of the Second Planktonic Conference, Roma 1969, 739-785.

Nuttall, W.L.F. 1928. Tertiary Foraminifera from the Naparima Region of Trinidad, (B.W.I.). Quarterly Journal of the Geological Society, 84, 57-115.

Perch-Nielsen, K. 1985. Cenozoic calcareous nannofossils. In: Bolli H.M., Saunders J.B. \& Perch Nielsen K., (Eds.), Plankton Stratigraphy. Cambridge University Press.

Toumarkine, M. \& Luterbacher, H.-P. 1985. Paleocene and Eocene planktic foraminifera. In: Bolli H.M., Saunders J.B. \& Perch Nielsen K., (Eds.), Plankton Stratigraphy. Cambridge University Press.

Vaughan, T.W. \& Cole, W.S. 1941. Preliminary Report on the Cretaceous and Tertiary Large Foraminiferas of Trinidad, B.W.I.. Geological Society of America, Special Paper, 30, 1-137. 